\title{
Nasrettin Hoca Fıkralarında Yoksulluk Eleştirisi ${ }^{1}$
}

\author{
Criticism of Poverty in Nasrettin Hodja Anecdotes
}

Selma Sol*

$\ddot{O}_{z}$

Bu çalışma Nasrettin Hoca fikralarında dile getirilen "yoksulluk eleştirisi”"ni ortaya koymayı amaçlamıştır. Bu nedenle öncelikle kavramsal olarak yoksulluk olgusu üzerinde durulmuştur. Söz konusu olgunun kavramsal ve kuramsal çerçevesi gözden geçirilerek, Nasrettin Hoca fikralarından hareketle, fikra metinlerine sindirilmiş yoksulluk göstergeleri tespit edilmiştir.

Yoksulluk kavramı, sözlük anlamı ile "variyetsizlik, sefillik, sefalet ve fakirlik" olarak açıklanmaktadır. İnsanoğlunun bedensel varlığını sürdürebilmesi için gerekli olan beslenme, barınma, giyinme ve sağlığını koruma gibi temel ihtiyaçlarını kısmen ya da büyük oranda karşılayamadığı zaman, söz konusu durum yoksulluk kavramı ile ifade edilir. Genellikle beşeri ihtiyaçlar söz konusu olduğunda karşılaştığımız bu kavram, birden fazla boyutu olmakla birlikte, toplumdan topluma hatta kişiden kişiye bile değişkenlik gösterebilir. Ekonomik, kültürel ve sosyolojik olarak farklı başlıklar altında değerlendirilen yoksulluk kavramı, toplumların kültürüne, sanatına ve edebiyatına da konu bakımından malzeme teşkil etmektedir. Yoksulluğu ve getirilerini/sonuçlarını

* Dr. Öğretim Üyesi, Trakya Üniversitesi, Edebiyat Fakültesi, Türk Dili ve Edebiyatı Bölümü, selmasolergin@trakya.edu.tr 
konu alan kültürel ve sanatsal çeşitlilikten de bahsetmek mümkündür.

Türk halk edebiyatı çerçevesinde de sosyal bir eleştiri konusu olarak yoksulluğun tema olarak işlendiği hikâye, türkü, ninni ve fikra gibi geleneksel türlerin varlığı bilinmektedir. Bu düşünceden hareketle, bu çalışma bir halk filozofu olan Nasrettin Hoca'ya bağlı olarak anlatılan fikralardaki yoksulluk kavramı ve eleştirisini sosyolojik bir bakış açısıyla incelemeyi hedeflemiştir. Halk edebiyatında tahkiyeye dayalı bir tür olarak fikra, ilgili toplumun sosyal ve kültürel ortamında şekillenir. Söz konusu türde, fikra tipinin şahsiyetinde, mizah ve eleştirel düşünce harmanlanarak gerek bireysel gerekse toplumsal çıkarımlar yapılır. Ferdî ya da toplumsal aksaklıklar, sosyal düzendeki karmaşa, fikranın dilinde mizahi bir boyut kazanarak gülme dinamiği sağlanır. Bu çalışma kapsamında yapılan incelemede, Nasrettin Hoca'ya atfedilen fikra metinlerinden hareketle hem bireysel hem de toplumsal açıdan değerlendirilebilecek bir eleştiri konusu olarak "yoksulluk" temasına dair göstergeler tespit edilmeye çalışılmıştır.

Anahtar sözcükler: fikra, Nasrettin Hoca, yoksulluk eleştirisi, mutlak yoksulluk

\section{Abstract}

This study aims to reveal the "poverty criticism" that is expressed in Nasrettin Hodja's anecdotes. For this reason, firstly, the phenomenon of poverty is emphasized conceptually. The indicators of poverty engraved into jargon texts have been identified from the Nasrettin Hodja anecdotes by reviewing the conceptual and theoretical framework of this phenomenon.

The concept of poverty is literally described as"poorness, misery, hunger and beggary". The situation, under which human beings cannot meet their basic needs, such as nutrition, shelter, clothing and health that are necessary to sustain their physical existence partially or largely, is expressed by the concept of poverty. This concept that we usually encounter when it comes to human needs has more than one dimension and it might vary from society to society and even from person to person. The concept of poverty evaluated under different categories like economic, cultural and sociological, takes part in cultures, arts and literature by means of a subject matter. It is possible to mention cultural and artistic diversity that discuss poverty and its returns/results.

The existence of traditional types is a known fact, such as story, ballad, lullaby and anecdotes/traditional tales in which the poverty is discussed as a theme, as a social criticism subject within the framework of Turkish folk literature. From this point of view, this study aims to examine the concept and critique of poverty in the anecdotes described in connection with Nasreddin Hodja with a sociological perspective. Anecdote, as a type which is based on narrating in folk literature, is shaped inside the social and cultural environment of the society. In this aforementioned type, in the personality of anecdotes, both 
individual and social inferences are made by combining humor and critical thinking. Individual or social troubles and chaos in social order obtain a humorous dimension in anecdote dialect and laughing dynamic is created by this way. In the examination held within the scope of this study, the indicators about the theme of "poverty" as a criticism subject, which can be evaluated both individually and socially, was tried to be determined with reference to the anecdote texts that were attributed to Nasrettin Hodja.

Keywords: Nasrettin Hodja, anecdotes, poverty criticism, absolute poverty

\section{Giriş: Yoksulluğun kavramsal ve kuramsal çerçevesi}

Sosyoloji Sözlüğü'nde genellikle maddi kaynaklardan, bazen de kültürel kaynaklardan yoksun kalındığını ifade eden bir durum (Marshall, 1999,825) olarak tanımlanan yoksulluk, insanoğlu için tarihin her döneminde baş etmek zorunda kaldığı en önemli sorunlardan biridir. Oktik'e göre ise yoksulluk, genel olarak yeterli kaynak ve gelir sahibi olmama konumuyken, insan yaşantısının onurlu bir şekilde sürdürülebilmesi için gerekli olan gıda, su, giyecek, barınacak ev, sağlık hizmetlerinden yararlanma ve güvenlik gibi temel insanî gereksinimlerden yoksun olmak olarak tanımlanabilir. Yoksulluk, aynı zamanda, sosyal, politik ve psikolojik alanlarda yetkinsizlik olarak da kabul edilebilir (Oktik, 2008,25).

Yoksullukla ilgili yapılmış öncü sayılabilecek pek çok çalışmanın, ekonomi ve iktisadi bakış açısı taşıdığı görülmektedir. Ancak özellikle 20.yy.' dan itibaren yapılan çeşitli çalışmalar, yoksulluk kavramının daha farklı bilim dallarını da ilgilendirdiğini ortaya koymaktadır. Söz konusu kavramın farklı disiplinlerce ele alınması göstermiştir ki daha tanımından itibaren yoksulluk kavramı bir netliğe ulaşamamıştır. Şüphesiz bu belirsizlikte, ekonomik, sosyolojik, kültürel ve psikolojik olarak farklı bilim dallarının kendi ölçütlerine göre yoksulluğu tanımlama ve kuramsal çerçevesini çizme denemeleri ve yoksulluk kavramının hangi disiplinle ele alınırsa alınsın yaşa, cinsiyete, fiziksel, kültürel ve toplumsal özelliklere göre sürekli değişkenlik göstermesi son derece etkilidir. Bu nedenle yoksulluk kavramı ve ölçütlerini -araştırmanın amacına ve ortaya koymaya çalıştığı iddialarına göre- hangi disipline dayanarak ele alınıyorsa ilgili bilim dalı dâhilinde kavramsal ve kuramsal çerçeveyi genişletmek hatta değiştirmek durumu da ortaya çıkmaktadır.

Yoksulluk üzerine yapılmış çeşitli çalışmalarda, yoksulluğun nitelik ve nicelik özelliklerine vurgu yapılması hemen hemen pek çok disiplinin, yoksulluk kavramını ortak başlıklar altında değerlendirebilmesini de mümkün kılmıştır. Buna göre, yoksulluğu mutlak, göreli, insanî, objektif/subjektif, kırsal/kentsel, kültürel gibi başlıklar altında değerlendirebilmek, kavrama dair disiplinler arası çalışmalara da mecra sağlamaktadır. Bu bağlamda, farklı konularda temellendirilerek ele alınmış yoksulluk kavramına dair incelemelerde, karşımıza çıkan ana başlıklardan biri de mutlak ve göreli yoksulluk değerlen- 
dirmeleridir. Aksan'a göre, “yoksulluğu anlamaya ilişkin olarak sosyologlar ve araştırmacılar tarafindan tercih edilen başat iki farklı yaklaşım mutlak ve göreli yoksulluktur. Bu başat yaklaşımlar hem yoksulluğu anlama hem de açıklama bağlamında önemli sınırlar çizerken araştırmacıya yoksulluğa hangi perspektiften bakacağı noktasında yardımcı olmaktadır. Söz konusu yaklaşımların yanı sıra yoksulluğun olgu ve sorun boyutlarına işaret ederek toplumsal görünümlerini tanımlayan birçok kavramsallaştırmanın varlığından bahsedilebilir. Bunlar genel olarak birincil yoksulluk, insanî yoksulluk, döngüsel yoksulluk, subjektif yoksulluk, ultra/olağanüstü yoksulluk, gelir yoksulluğu, yeni yoksulluk, kalıcı yoksulluk, kırsal ve kentsel yoksulluk, kadın ve çocuk yoksulluğu olarak sıralanabilir” (Aksan, 2012,11). Mutlak ve göreli yoksulluğa dair Açıkgöz'ün tespitleri ise, "Mutlak yoksulluk, gıda, barınma, giyim gibi temel ihtiyaçlardan yoksun olma halini ifade ederken, göreli yoksulluk kapsam bakımından daha geniş bir alana işaret etmektedir. Göreli yoksulluk, temel ihtiyaçların yanı sıra, sağlık, eğitim, temiz içme suyu gibi hizmetlere ulaşma ve doğumda yaşam beklentisi gibi durumları da içeren bir kavramdır. Yani bu kavramla insanların imkânları ve yoksunlukları da yoksulluk kapsamına dâhil edilmektedir. Göreli yoksulluk toplum bazında değerlendirilen bir kavramdır. Bu kavramla bir toplumda yalnızca aç olanlar veya evsizler değil, aynı zamanda toplumun genel tüketim düzeyinin altında kalanlar da göreli olarak "yoksullar" kategorisine sokulmaktadır" (Açıkgöz, Yusufoğlu, 2012, 84).

Yoksulluğu çeşitlendiren bir takım toplumsal etmenler söz konusudur. Toplumların geleneksel ve kültürel yapılanmaları, iş gücü bakımından genellikle eşitsizlik üzerine kurulan kadın ve erkeğe dair toplumsal algı ve gelir/kazanç dağılımlarındaki dengesizlik söz konusu etmenlerden sayılabilir. Kitlesel bir sorun olarak değerlendirilen yoksulluğu bertaraf etmek/edebilmek için tarihin her döneminde farklı öneri ve çözümler uygulamaya konmuştur. Ancak tarihsel zaman akış1 içerisinde değişen iktisadi ve ekonomik yapı, söz konusu çözüm önerilerini etkisiz bırakmıştır. Kısacası yoksulluk, insanoğlu için tüm zamanlara yayılmış fenomen sorunlardan biri ola gelmiştir.

\section{1. İnceleme}

Daha ziyade ekonomik ve finansal bir terim olarak çağrışım yapan yoksulluk olgusu, insan yaşamının her döneminde, kısmen hayati kısmen de tahammül edilebilir bir sorun olarak karşımıza çıkmaktadır.

Yoksulluğun çok boyutlu inceleme alanlarından biri de ekonomik ve sosyolojik bir etki olarak ve halk kültürüyle harmanlanarak toplumların edebiyatına yansıma biçimidir. Buradan hareketle bu çalışmanın konusu, Türk halk edebiyatının en meşhur fikra tipi olan Nasrettin Hoca'ya bağlı olarak anlatılan fikralardaki yoksulluk eleştirisinin çeşitli açılardan ortaya konması olarak belirlenmiştir.

Yoksulluğun nedenleri üzerine yapılmış çalışmalara bakıldığında işsizlik, eğitim eksikliği ve göç dalgalanmaları gibi sorunların başı çektiği görülmektedir. Hâl böyleyken 
yoksulluk kavramının daha ziyade modern zamanlara ait bir sorun olduğu düşünülebilir. Ancak, toplumsal duyuş ve düşünüşün, kitleleri derinden etkileyen çeşitli hadiselerin gerek bireysel edebiyat eserlerine gerekse halk kültürünün etkisiyle şekillenmiş anonim edebiyata yansımaları göz önüne alındığında, yoksulluk kavramının asırlardır ciddi bir malzeme teşkil ettiği göz ardı edilemez. "Edebiyatın Tükenmez Malzemesi: Yoksulluk" başlıklı çalışmasında Boynukara, "Hangi çağda, hangi dilden, hangi toplumda ve hangi dinden olursa olsun yoksulluk edebiyat için en az aşk kadar önemli bir kaynak ve bitmez tükenmez bir malzeme olmuştur. Şiirde tiyatroda, masalda, romanda bütün edebi türlerde tartışılmaz bir yere sahiptir. Toplumsal eleştiri temelli yapıtlardan, konusu aşk, kahramanlık, fedakarlık olanlara değin sayısız çalışmanın merkezinde, başında ya da sonunda yoksulluk vardır. Yoksulluğun acısına, neden olduğu sorunlara ve umutsuzluğa adanmış olan eserlerin yanında zaman zaman dramatik etkinliği artırmada ikinci derecede bir öğe olarak da kullanılmıştır. Yoksulluğun oynadığı rol, işgal ettiği yer ve etkisi çıkarıldığında, hiçbir işe yaramayacak yüzlerce modern ve klasik eser vardır" demektedir (Boynukara, 2003,197).

$\mathrm{Bu}$ bağlamda, sözlü ve yazılı gelenekte yoksulluğun tematik kullanımının, söz konusu kavramın sosyolojik ve ekonomik çözümlemelerinden daha eski olduğu iddia edilebilir. Bu açıdan, Türk halk edebiyatı kapsamında değerlendirdiğimiz, yoksulluk temasını işleyen ya da bu temaya kısmen yer veren atasözleri, deyimler, kıssalar, masallar, türküler, maniler, didaktik hikâye, fikra vb. gibi sözlü gelenek ürünlerinin bolluğu ve anlatı geleneği dâhilinde tarihsel eskilikleri dikkat çekicidir. Bu çalışma kapsamında ise söz konusu geleneksel anlatı türlerinden Nasrettin Hoca'ya bağlı olarak anlatılan fikralardaki yoksulluk eleştirisi üzerinde durulmuştur.

Fıkra metinlerinde, yoksulluk halinin bir başka yansıması olarak "fakirlik" olgusu ile de sıklıkla karşılaşmaktayız. Fakirlik ve yoksulluk kavramlarını karşılaştırarak farklılıklarına değinen Çiğdem'e göre yoksulluk, "Yoksulluk şartlarının ve yoksulluk durumunun "resmileştirilmesi" ve "anlatılanmasını" kolaylaştıran bir kavramdır; fakirlik, eğer bu kavrama bir mistik anlam yüklenilmemişse, her zaman daha şiddetli bir içerlemeyi ve gerilimi gösterir. Daha yüzeysel bir ayrım, yoksulluğun daha seküler, fakirliğin ise daha dinsel bir yoksulluk anlatısına izin verdiği şeklinde yapılabilir" (Çiğdem, 2016, 206) demektedir.

Bununla birlikte fikra metinlerinde yer alan "fakirlik" olgusunun kullanımına dair tespitlerini dile getiren Bilgin, "Fıkralarda sık sık karşımıza çıkan fakirlik ise, özellikle kırsal kesimdeki yoksulluğa vurgu yapar. Ülkede zaman zaman ortaya çıkan ekonomik krizler bu yoksulluğu daha da pekiştirmiş olmalıdır. Örneğin 16. yüzyılın ortalarından, özellikle 1570'lerden itibaren İngiltere, kıta Avrupa's1, Akdeniz ülkeleri ve İran'a kadar büyük bir coğrafyada küresel denilebilecek bir enflasyon yaşanmış, bu ekonomik bunalımdan en fazla etkilenen ülkelerden biri de Osmanlı Devleti olmuştu (Braudel'den akt. Bilgin, 2005). 1635 yılından itibaren 12 yıl Osmanlı topraklarını dolaşan Kâtip Çelebi gördüğü köylerin çoğunun perişan olduğunu söyler (Kâtip Çelebi'den akt. Bilgin, 
2005). 1760'lardan sonra Osmanlı ekonomisi tekrar bir daralma yaşamış ve 1790-1800 yılları civarında o zamana kadar görülmemiş bir şekilde yıllık \% 5 civarında enflasyon yaşanmıştı (Genç’ten akt., Bilgin, 2005). Hicvin özellikle sosyal, ekonomik ve siyasî krizlerin yaşandığ 1 dönemlerde daha da revaç bulduğunu düşündüğümüzde (Çiftçi'den akt. Bilgin, 2005) konuyla ilgili fikraların çokluğu daha iyi anlaşılabilir” (Bilgin, 2005, 364) demektedir.

Sözlü ve yazılı edebiyat geleneği dâhilinde, halkın muhayyilesinde teşekkül eden halk kahramanlarına bağlı olarak anlatılan tahkiyevî ürünlerde, son derece geniş bir muhteva söz konusudur. Anlatının ait olduğu döneme dair çeşitli konulardaki toplumsal algıyı göstermekle birlikte, bireyler arası ilişki ve maceralardan, iktidar ve halk ilişkisine, yüceltilmiş ya da yasaklanmış dini ve ahlaki öğretilere değin, evrensel boyuta da taşınabilecek çeşitli duygu ve düşünceler, yerleşik toplumsal kabuller anlatı geleneğimizin zengin muhtevasını kısmen oluşturmaktadır. Masaldan efsaneye, geleneksel hikâyeden fikraya kadar söz konusu ürünlerin hemen hemen hepsinde kahraman kadrosu, yaşadıkları toplumun dünya görüşünün kısmen temsilcisi durumundadır. Söz konusu anlatı türlerinden özellikle fikra türü, Türk halkına özgü gelişmiş yergi/eleştiri dinamiğiyle gülme mekanizmasını tetikleyen bir tür olarak dikkat çekicidir. Türk halk edebiyatında fikra türü söz konusu olduğunda akla ilk gelen, hiç şüphesiz ünü Türkiye sınırlarını çoktan aşmış olan Nasrettin Hoca ve ona bağlı olarak anlatılan fikra külliyatı gelmektedir. Nitekim Özdemir de Hoca’yı, her türlü ayrımı ortadan kaldıran dahası yaşamı herkes için eşitlemek adına Türk halkı tarafından yaratılmış bilge tipi olarak değerlendirir (Özdemir, 2010, 31).

\section{Kamusal/İnsani yoksulluk eleştirisi}

Toplumsal değerler ve ekonomi arasındaki ilişki sosyoekonominin ilgi alanı olarak karşımıza çıkmaktadır. Bu bağlamda sosyoekonomik açıdan en temel toplumsal ayrışma zenginlik/yoksulluk kavramlarını doğurmaktadır. Nitekim Ak'a göre de "yoksulluğun kavramsal mahiyeti ve boyutu toplumların farklı sosyoekonomik gelişmişlik düzeylerine göre değişebilmekte ise de hayatî sosyal risk taşıması açısından bütün toplumların en önemli ortak sosyal sorunlarından biri olduğu söylenebilir. Yoksulluk denilince aklımıza çoğu zaman zenginliğin karşıtı olan fakirlik, yani sefalet, açlık, yokluk, muhtaçlık, hayatla sürekli mücadele, hayatta kalabilme savaşı, temel ve zorunlu ihtiyaçları yeterince karşılayamama, yeterli varlığa sahip olamama ve gelirden mahrum olma gelmektedir" (Ak, 2016, 296). Bu taraftan bakıldığında yoksulluk olgusunun, bireysel ve kamusal açıdan sadece zaruri kaynak ve gelirlere erişim açısından eksikliği değil aynı zamanda kabul edilmiş genel gelir ve kaynak firsatlarına erişimin de olmadığı durumları kapsaması da dile getirilebilir. Bu nedenle yaşamsal temel ihtiyaçların karşılanması, ait olan kültüre göre kabul edilmiş yaşam standartları söz konusu olduğunda yoksulluğa dair birçok alt başlıklandırma, gündeme gelebilmektedir. Gelir yoksulluğu ve insani yoksulluğu kavramları söz konusu duruma örnek gösterilebilir. 
İnsanoğlunun yeme, içme gibi temel yaşamsal ihtiyaçlarını karşılamada maddî yetersizlik içinde bulunma hâli gelir yoksulluğu ve insanî yoksulluk kavramları ile karşılanmaktadır. ${ }^{2}$ Söz konusu yoksulluk hâlinin gerek reel yaşamda gerekse yoksulluğu sosyal bir eleştiri olarak dile getiren fikra metinlerindeki en temel göstergelerinden biri ise "açlık" hâlidir. Bu çalışma kapsamında taranan Nasrettin Hoca fikralarında da hocanın gelir yoksulluğunu ortaya koyan, dolayısıyla açlıktan ve yeterince yiyecek temin edememekten dem vuran fikralar tespit edilmiştir. Söz konusu fikralarda mizah unsurunun, Nasrettin Hoca'nın dilinden, karşısındaki tipe doğrudan yaptığ 1 yoksulluk eleştirisiyle sağlandığını görmekteyiz. İncelenen fikra metinlerinde Nasrettin Hoca, içinde bulunduğu yoksulluğu kanıksamış görünmekle birlikte, kendi sahip olamadığı ve varlık alameti olarak değerlendirdiği bir durumun da adeta sorgulamasını yapar. Ana çerçevede sosyal bir tenkit realitesi olarak karşımıza çıkan, ancak yorum çerçevesi olarak değerlendirebileceğimiz hüküm bölümlerinde "eleştirinin doğrudan karşısındaki muhatap üzerinden" yapılan fikra metinlerinden bazıları şöyledir;

"Ne Duruyorsun?" (Kabacal1, 1991,126) adlı fikrada Hoca'nın içinde bulunduğu yoksulluğun göstergeleri "aç olma" hâli ve "karnını doyuracak yiyecek almaya parası olmama" hâliidir. Her iki göstergeye dayanarak Hoca'nın mutlak bir yoksulluk içinde olduğunu söyleyebiliriz.

\begin{tabular}{|l|c|}
\hline $\begin{array}{c}\text { Ana Çerçeve } \\
\text { Hoca Konya'ya gider. Dolaşırken karnı ac1- }\end{array}$ & Yorum Çerçevesi \\
kır ancak ekmek alacak parası yoktur. Burnuna \\
mis gibi ekmek kokusunun geldiği bir firına gi- \\
rerek ısrarla ekmeklerin kimin olduğunu sorar. \\
$\begin{array}{l}\text { Fırıncı, sorusunu üsteleyen Hoca'ya kızgınlıkla } \\
\text { "hepsi benim" der. }\end{array}$
\end{tabular}

$\mathrm{Bu}$ fikrada Hoca'nın da içinde bulunduğu görülen mutlak yoksulluk kavramı dâhilinde bireyin yaşamını sürdürebilmesi için gerekli asgari şartları -öncelikle beslenme gibi- sağlayamaması durumundan bahsedilebilir. Aktan ve Vural'a göre de "mutlak yoksulluk, hane halkı ya da fertlerin biyolojik olarak kendilerini üretebilmeleri için ihtiyaç duydukları asgari gelir ve harcama düzeyidir. Tanımın yaşamı sürdürebilmek için gerekli olan asgari besin bileşenlerini veya kaloriyi esas alması ona mutlaklık niteliği kazandırmaktadır" http://www.canaktan.org/ekonomi/yoksulluk/birinci-bol/aktan-vural-yoksulluk.pdf.

"Utancından" (Kabacal1, 1991, 127) adlı fikrada ise yoksulluk göstergesi eve giren hırsızın çalacak hiçbir şey bulamamış olmasıdır. İlgili fikrada, hırsıza olanca iyimserliği ile yaklaşan Hoca'nın, yoksulluğundan utandığını görürüz. 


\section{Ana Çerçeve}

Hoca, evine hırsız girdiğini fark edince yüklüğe saklanır. Çalacak bir şey bulamayan hırsız, yüklüğe bakmak isteyince hoca ile karşılaşır.

\section{Yorum Çerçevesi}

Hoca: Kusura bakma, evden çalabileceğin bir şey yok diye utandım da saklandım, der.

"Cenaze Bize Geliyor" (Kabacal1, 1991, 140) adlı fikrada ise Hoca'nın muhatab1 karısıdır. İlgili fikrada ısınma ve yiyecek gibi en temel ihtiyaçlardan mahrum olduklarının vurgusu yapılarak geniş anlamlı bir maddi mahrumiyet yaşandığı söylenebilir.

\begin{tabular}{|c|c|}
\hline $\begin{array}{l}\text { Ana Çerçeve } \\
\text { Akrabaları cenazelerinin ardından dövüne- } \\
\text { rek, "karanlık yerlere gidiyorsun, gittiğin yerde } \\
\text { ne ates ne de yiyecek var!" diye ağlasırlar. }\end{array}$ & $\begin{array}{l}\text { Yorum Çerçevesi } \\
\text { Bunu duyan Hoca: Hatun, bu cenaze mutla- } \\
\text { ka bize geliyor!, der. }\end{array}$ \\
\hline
\end{tabular}

"Ördek Çorbası İçiyorum” (Sakaoğlu, Alptekin, 2009, 164) adlı fikrada ise yoksulluğun nedeni olarak, Nasrettin Hoca'nın hayattayken büyük bir kitlığa şahit olmas1 gösterilir. Bu fikra aynı zamanda genelin halini yansıtan bir eleştiri mahiyetindedir. Hoca'nın şahsında, kitlesel olarak maruz kalınan kıtlık dolayısıyla yoksulluk hâli ironik bir dille eleştirilir.

\begin{tabular}{|r|c|}
\hline \multicolumn{1}{|c|}{ Ana Çerçeve } & \multicolumn{1}{c|}{$\begin{array}{c}\text { Yorum Çerçevesi } \\
\text { Hoca hayattayken, bir lokma ekmeği bile } \\
\text { bulamadıkları büyük bir kıtlık olur. Akşehir gö- } \\
\text { lüne geldiğinde, göldeki ördeklerden yakalamak } \\
\text { ister ancak başaramaz. Yorgun argın, göl kenarın- } \\
\text { da bir ağacın altına oturup ördek yakalamak için } \\
\text { kullandığı kuru ekmek parçalarını göle batırıp } \\
\text { yemeye başlar. Hoca'yı görenler hayretle kendi- } \\
\text { sine ne yaptığını sorarlar. }\end{array}$} \\
\hline
\end{tabular}

"Yoksulun malı Gözü Önünde" (Kabacalı, 1991, 136) adlı fikrada ise hüküm bölümünde, yoksulluk kültürüne dâhil edebileceğimiz genel bir yargı bulunmaktadır. Neredeyse özlü söz kıvamına erişmiş bu yargı, yoksulluğa ve yoksul olmaya dair çizilen ezberlenmiş bir tabloyu ortaya koymaktadır. Şüphesiz bu tablonun oluşmasında, yoksulların kendileri hakkında oluşturdukları algı kadar yoksul sınıfından sayılmayanların da yoksula ve yoksulluğa dair kalıplaşmış düşünce biçimleri de etkilidir. Bu fikranın alt metninden "yoksulun malı zaten yoktur olsa da kalıcı ve faydalı değildir" eleştirisi okunabilir. 


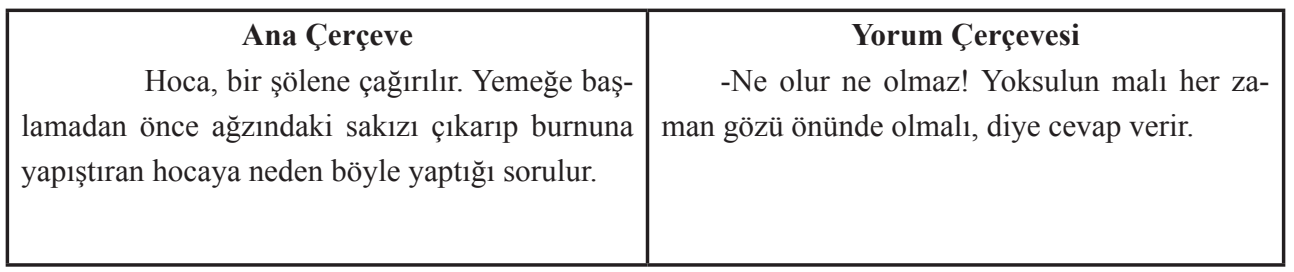

\section{3. İktidara yönelik yoksulluk eleştirisi}

Giddens ve Sutton'a göre yoksulluk açıklamaları ya birey ya da toplumsal kurumlar üzerine odaklanmıştır. Bunlar sırasıyla "mağduru suçlama" ve "sistemi suçlama" kuramları olarak tanımlanır (Giddens, Sutton, 2018, 203). Dünya üzerinde insan toplulukları, kendi geliştirdiği çeşitli siyasi ve ekonomik sistemler içinde yaşamaktadır. Yönetimde söz sahibi kabul edilen siyasi/idari otoriteler, çoğu kez ekonomik sistemin belirleyici ve yönetici aktörleri olarak da görülürler. Bu sebeple her ne kadar çok boyutlu bir sorun olsa da yoksulluğa dair eleştirilerden bir kısmı görev ve sorumluluk alanı içinde olduğu düşüncesiyle yönetici/iktidari yapı üzerinde yoğunlaşmaktadır.

Hoca'ya bağlı olarak anlatılan fikra metinlerinde, devlet yönetimini elinde bulunduran veya devletin gücünü kullanma tasarrufu olan anlamında kullandığımız "iktidar" yapısı bazı görev ve makamlarla temsil edilmektedir. Şişman, "Nasreddin Hoca Flkralarındaki Şahısların Sosyal Statülerine Göre Sinıflandırllması ve Değerlendirilmesi” başlıklı yazısında "Bu çalışmamızda Nasreddin Hoca'dan ziyade onun muhataplarına yani fikralardaki diğer şahıslara bakmayı hedefledik. Bunu yaparken sadece metinden yola çıkarak bazı tespitlerde bulunduk. Ancak bu çalışmanın sınırlarının, yapısalcı bir çözümlemeyle, Hoca'nın muhataplarının metne ve metindeki anlam kodlarının oluşumuna ne denli etki yaptıklarını ortaya çıkarabilecek genişlikte olamayacağından hareketle; yalnızca onların sosyal aidiyetleri, konumları, ilişkileri, alışkanlıkları ve yaşam felsefeleri üzerinde durmaya çalıştık" (Şişman, 2010,133) der ve toplum nazarında bireye göre iktidarın temsili sayılan kişiler için "V. Yöneticiler, 1. Kadı, 2. Sultan/Padişah, 3. Sipahi, 4. Subaşı," (Şişman, 2010, 140-141) şeklinde tasnifleme yapar.

Yıldırım'a göre ise, "Türk fikralarının büyük bir bölümünün konusu idareci tabaka ile halk arasında geçen vakalardır. Bu vakalarda halk, umumiyetle doğrudan doğruya idarecilerin karşısına çıkmaz. Düşünce, tutum ve davranışını kahramanın ağzından ifade eder. Halk, kahramanını idareci tabakadan kendisine ters düşen her tipten insanın karşısına çıkarır. Padişah, sadrazam, vezir, kazasker, şeyhülislam, beylerbeyi, yeniçeri ağası, subaşı, kadı, vali, kaymakam, muhtar vb. idareciler, bu tipler arasında yer alır" (Yıldırım, 1999, 5).

Mizah hakkındaki yaygın görüşlerden biri her türlü otoriteye karşı etkili bir muhalefet aracı olarak kullanılabilmesidir. Kurgan'a göre, "Nasrettin Hoca mizahı, kimi zaman haksızlığa, zulme karşı koymakla beraber, bir yandan da umutsuzluğu, fukaralığı, hatta 
açlı̆̆1 dile getiren acı bir mizahtır" (Kurgan, 1986, 45). Yokluk, fakirlik gibi kitleleri olumsuz etkileyen durumları konu edinen fikra metinlerinde, Nasrettin Hoca'nın, iktidara ve onu temsil eden güçlere karşı sosyal adaletin savunucusu olma rolünü de üstlendiğini görmekteyiz. Aynı zamanda uzlaştırıcı bir yaklaşım da sergilemektedir. Hem eleştiren hem de uzlaşı sağlamaya çalışan bu fikra metinlerini oluşturan bilincin, Türk kültüründeki devlet ve devleti temsil eden iktidarî yapıdan beklentiler ve bu kavramlara duyulan saygı ile atfedilen kutsiyet olduğu söylenebilir. Bu sebepledir ki ataerkil toplumlarda söz konusu yapı "baba" sıfatıyla da anılır.

İncelenen Nasrettin Hoca fikralarında, Hoca'nın bazen halkı temsil ettiği bazen de içinde bulunduğu görev icabı idareci tabakaya mensup olduğu tespit edilmiştir. Her iki durumda da Hoca'nın, fikralarının karakteristiğine uygun olarak cesurca konuştuğu ve adaletli bir eleştiriden yana tavır gösterdiği de görülmektedir. Bu nedenle Hoca fikralarında, sosyal eleştiriye sebebiyet verebilecek diğer konu başlıklarında da olabileceği gibi yoksulluk konusunda da birey ve idareci tabaka mizahi bir eleştiriyle karşı karşıya getirilir. Bireyin içinde bulunduğu ekonomik sıkıntıların ve toplumsal gelir düzeyindeki dalgalanmalı yapının neden olduğu yoksulluk, toplumsal gerçeklik düzleminde ele alınır. Yoksulluk göstergesi olarak değerlendirilen açlık hâlinin ve sonuçlarının ortaya konduğu bir Nasrettin Hoca fikrasında, Hoca, karşısındaki padişaha korkusuzca düşüncesini söyler. ${ }^{3}$

\begin{tabular}{|r|c|}
\hline $\begin{array}{c}\text { Ana Çerçeve } \\
\text { Hoca bir gün padişaha kızarmış bir ördeği hediye götürür }\end{array}$ & $\begin{array}{c}\text { Yorum Çerçevesi } \\
\text { Hoca, "Sultanım, o davulun }\end{array}$ \\
ancak çok açtır ve dayanamayıp yolda ördeğin bir budunu yer. & $\begin{array}{c}\text { tokmağını siz yeseydiniz, vallahi } \\
\text { Padişah, bir budun neden eksik olduğunu sorunca da, "Bizde } \\
\text { ördeklerin tek budu vardır" diyerek bahçedeki tek ayaklarını } \\
\text { kanatlarının altına çekerek duran ördekleri gösterir. Padişah da } \\
\text { davulcusunu çağırarak çalmasılnı söyler. Gürültüyü duyan ör- } \\
\text { dekler iki ayaklarıyla koşmaya başlar. Bunun üzerine Padişah } \\
\text { da "Hani sizin orda tek bacaklıydı?", diye sorar. }\end{array}$ \\
\hline
\end{tabular}

"Duman Satan" (Kabacal1, 1991, 220) adlı fikrada ise Hoca'y1 iktidarı temsil eden Akşehir kadısı rolünde görmekteyiz. İlgili fikrada Hoca, yoksulun birini haksız yere dava eden kişiye hak ettiği cevabı layıkıyla verir. Bu sayede Hoca, iktidarı temsil eden bir tip olarak yoksulun hakkını korumuş ve herhangi bir itiraza mahâl bırakmayan çözümüyle yoksul, kebapçı ve iktidari yapı arasında uzlaşı sağlamıştır. 


\begin{tabular}{|l|c|}
\hline $\begin{array}{r}\text { Ana Çerçeve } \\
\text { Yoksulun biri, Akşehir çarşısından geçerken açlığına da- } \\
\text { yanamayıp koynundan çıkardığı ekmeği, önünden geçtiği ke- } \\
\text { babın dumanına tutarak yer. Tam giderken, kebapçı yakasına } \\
\text { yapışıp para ister. İş büyür, Akşehir kadısı Nasrettin Hoca'nın } \\
\text { karşısına çıkarlar. Hoca her ikisini de dinledikten sonra yoksu- } \\
\text { la dönüp, "Ne kadar paran varsa bana ver" der. Hoca, adamın } \\
\text { şaşkınlıkla verdiği para kesesinden birer birer paraları çıkarıp } \\
\text { sayar. Sonra da kebapçıya paraların sesini duyup duymadığını } \\
\text { sorar. Adam, "Duydum” der. Hoca paraları tekrar kesesine ko- } \\
\text { yup adama geri verir ve kebapçıya da: }\end{array}$ \\
\hline
\end{tabular}

"Şu Koca Tasla" (Kabacalı, 1991, 215) adlı fikrada da Hoca'nın, mollalar üzerinden sisteme yönelik bir yoksulluk eleştirisi yaptığı görülmektedir. Mutlak bir yoksulluk hâli içinde bulunan Hoca'nın, mevcut durumu iktidari yapının temsilcileri sayılan mollalara ifade ediş biçimi "olmayan bir tas yemek" şeklindedir.

\begin{tabular}{|c|c|}
\hline $\begin{array}{c}\text { Ana Çerçeve } \\
\text { Hoca, mollaları eve yemeğe çağırır. Fakat karısı, evde ne } \\
\text { yağ, ne pirinç var! Ağza atılacak hiçbir şey yok! Odun bile } \\
\text { yok!, der. Eline bir tas alıp mollaların yanına giden Hoca: }\end{array}$ & $\begin{array}{l}\text { Yorum Çerçevesi } \\
\text {-Kusura bakmayın. Evde pi- } \\
\text { rinç, yağ, odun olsaydı pişirip bu } \\
\text { koca tasla ikram edecektim, der. }\end{array}$ \\
\hline
\end{tabular}

\section{Dini argümanlarla yapılan yoksulluk eleştirisi}

Yoksullukla ilgili iktisadi çalışmalarda, daha ziyade üzerinde durulan konuların başında yoksulluğun ilgili disipline göre tanımı ve sebeplerini belirleme çalışmaları gelmektedir. Yoksulluğun sosyokültürel bağlamını değerlendirmeyi eksenine alan çalışmalarda ise, yoksulluğu sadece ekonomik yönüyle değerlendirmek ve bireylerin zorunlu ihtiyaçlarını karşılayabilme düzeyine dair tasniflemeler ve durum tespitleri yapmak yeterli gelmemektedir. Toplumsal ve bireysel çeşitli konularda gerek halk bilimsel gerekse sosyolojik değerlendirmeler içeren incelemelerde de yazılı kanunların yanı sıra gelenekler, kitlesel kabuller ve inanışlara ilaveten din faktörü de ciddi bir önem arz etmektedir. Dolayısıyla, yoksulluk gibi hem toplumsal hem de bireysel düzeyde ele alınabilen bir kavramın, ilgili toplumun kültüründeki dini çerçevede yorumlanış biçimi bu açıdan önemlidir.

Yoksulluk olgusuna yönelik, semavi dinler kapsamında toplumsal bazda bazı kabuller söz konusudur. Dinî açıdan yoksulluğun kader, takdir-i ilahi, bu dünyaya ait bir imtihan meselesi olarak kabul edilişinin yanı sıra bireyler arası paylaşımın ve israfın önlenmesi sayesinde yoksullukla mücadele edilebileceği düşüncesi de yaygınlaşmıştır. Bu nedenle genel olarak dinsel yaklaşım, yoksullara karşı koruyucu ve yoksulluğu ber- 
taraf etmeye yöneliktir denebilir. Örneğin Tevrat, "Ülkede her zaman yoksullar olacak. Bunun için, ülkenizde yaşayan kardeşlerinize, yoksullara, gereksinimi olanlara eli açık davranmanızı buyuruyorum" (Tesniye, 15/11) derken İncil'de de "[Çok malı olan genç adam, malını satıp yoksullara vermekten çekinince] İsa öğrencilerine, 'Size doğrusunu söyleyeyim' dedi. 'Zengin kişi Göklerin Egemenliği’ne zor girecek. Yine şunu söyleyeyim ki, devenin iğne deliğinden geçmesi, zenginin Tanrı Egemenliği’ne girmesinden daha kolaydır" (Matta, 19/22-24) şeklinde ifadeler bulunmaktadır. Kur'an-1 Kerim'de ise, öncelikle bütün insanlar manevi olarak fakir ve Allah'a muhtaç iken zengin olan yalnızca Allah'tır denilmektedir" (Fâtır, 35/15, Muhammed, 47/38). Öte yandan fakirliğe değinen ayetlerin çoğunda da maddi anlamdaki yoksulluk üzerinde durulmuş ve bununla ilgili hükümlere yer verilmiştir. Bu ayetlerde fakirliğin Allah katındaki konumu, bunun bir utanç vesilesi yapılıp yapılmayacağı, kimlere yardım edilmesi gerektiği gibi konulara genel bir çerçeve üretecek şekilde değinilmektedir. Yanı sıra Kur'an'da fakirlik, Allah'ın insanları imtihan ettiği yollardan biridir ve ancak sabredenler bu imtihanı kazanmış olurlar (Bakara 2/155). Zenginlerin mallarında ihtiyacından dolayı yoksulun da bir hakk1 vardır (Mearic, 70/24-25) Zekâtın kimlere verileceğinin açıklandı̆̆ı bir ayette de (Tevbe, 9/60), fakirler (fukara) bu sıralamanın başında yer almaktadır”, (Subaş1, 2007, 82).

Okumuş’a göre, “Kur'an'da yoksulluk ve zenginlik, çeşitli ayetlerde konu edilir. Genellikle zengin olanların fakire yardım etmeleri gerektiğinin işlendiği ayetlerde yoksulluk olgusuna bir gerçeklik olarak yaklaşılır ve toplumsal eşitsizliğin adaletsizlik olarak yansımaması için toplumdan yoksulların kollanıp korunması ve gözetilmesi istenir. Kur'an'ın mal, servet, zenginlik, yoksulluk, sadaka, zekat ve infakla ilgili ayetlerine bakıldığında, İslam dininde yoksulların durumunu düzeltmenin ve sosyal adaleti sağlamanın topluma farz olduğu anlaşılır. Denilebilir ki zenginlik de yoksulluk da bir sosyal gerçekliktir; ama İslam, zenginlik ve yoksulluğun toplumda üstün olmanın ölçütü olmasına ve dengesizliklerin, mutsuzlukların oluşmasına yol açmasına izin verilmemesi ilkesiyle hareket edilmesini ister" (Okumuş, 2009, 446).

İslam inancı dairesinde şekillenen Nasrettin Hoca fikralarında da din mefhumu önemli bir yer teşkil etmektedir. Çalışmanın bu bölümünde sosyal bir eleştiri konusu olarak yoksulluğun, dini argümanlarla yapılmış eleştirisini içeren fikra metinlerinden seçilen örneklere yer verilmiştir.

Hoca fikralarının en meşhurlarından biri olan "Allah Versin” (Sakaoğlu, 2006, 38) adlı fikrada yoksulluk göstergesi olarak "dilenci/lik" mefhumuyla karşılaşırız. Parin'e göre, "Dilenci nosyonunun gündelik dildeki kullanımı ile sözlük anlamı arasında temelde bariz farklılıklar bulunmamaktadır. Dilenci kavramına lügatin biçtiği anlam "dilenerek geçinen, başkalarına el açan, geçimini dilenerek sağlayan, yokluktan, yoksulluktan sürekli yakınan; bir şeyi arsızca ve 1srarla isteyen kimse[leri]" betimleyen bir çerçeveye sahiptir" (Parin, 2009, 322). İslamî gelenekte ise çalışabilecek durumda olan kişilerin dilenmesine haram gözüyle bakıldığg bilinmektedir. İlgili fikrada, Nasrettin Hoca'nın, dilencinin dini bir argüman olarak kullandığı "sadaka" isteğine, yine dinî bir argümanla 
"Allah versin" diye karşılık verdiğini görmekteyiz. Bu fikranın alt metninden, İslamî gelenekle şekillenmiş dilenciliğe yönelik olumsuz eleştiri ve "rızkı veren Allah'tır" argümanı okunabilir.

\begin{tabular}{|c|c|}
\hline Ana Çerçeve & Yorum Çerçevesi \\
Hoca bir gün evinin damını aktarma işiyle epeyce yorul- & -Allah versin, der. \\
muşken aşağıdan kapısının 1srarla çalındığını duyar. Hele bir & \\
aşağıya iniver diyen adamı kıramaz ve kan ter içinde inip ka- & \\
pıyı açar. Kapıdaki dilenci, Allah rızası için sadaka ister. Tepe- \\
si atan Hoca, yukarıya çıalım da deyip dilenciyi dama çıarır.
\end{tabular}

"Kul Taksimi”" (Kabacal1, 1991, 168) adlı fikrada ise dini bir argüman olarak "Allah taksimi” sözünün kullanıldığını görmekteyiz. İlgili fikraya göre, kimine az kimine çok yapılan ceviz paylaşımı üzerinden, Allah tarafından her insana farklı miktarda rızık bağışlandığının bu nedenle kiminin daha zengin kiminin daha fakir olduğunun açıklaması yapılır. Bu fikraya göre, sosyal bir eleştiri olan yoksulluğun sebeplerinden biri olarak Allah'ın kulları arasında rızık ve mal paylaşımındaki eşitsizlik olduğunun vurgusu yapilmaktadir.

\begin{tabular}{|c|c|}
\hline $\begin{array}{l}\text { Ana Çerçeve } \\
\text { Hoca'nın yanına gelen çocuklar, getirdikleri bir torba ce- } \\
\text { vizi kendilerine paylaştırmasını ister. Hoca, Allah taksimi mi } \\
\text { yoksa kul taksimi mi yapayım diye sorunca, çocuklar Allah } \\
\text { taksimi olsun der. Bunun üzerine Hoca, birine bir avuç, di- } \\
\text { ğerine iki avuç, bir diğerine ise hiç vermemiş. Bu ne biçim } \\
\text { paylaştırma!?, diye soran çocuklara da: }\end{array}$ & $\begin{array}{l}\text { Yorum Çerçevesi } \\
\text {-Allah taksimi böyle olur. O ki- } \\
\text { mine az, kimine çok, kimine de hiç } \\
\text { vermez, demiş. }\end{array}$ \\
\hline
\end{tabular}

"Yokuş Çıkmak" (Kabacalı, 1991, 164), adlı fikrada ise yoksulluk göstergesi olarak geçim sıkıntısı çektiği belirtilen Hoca'nın, ilgili duruma yönelik eleştirisinin tam bir teslimiyet içinde verildiği görülmektedir.

\section{Ana Çerçeve}

Hoca yaşlanmış. Geçim sıkıntısı da çekiyormuş. Bir hemşehrisi:

-Hoca efendi Tanrı insanları niçin yaratmıştır?, diye sorar. Hoca hiç düşünmeden:

\section{Yorum Çerçevesi}

-Yokuş çıkmak ve borç ödemek, için der.

Bu bölümde değerlendirilen fikralarda yer alan yoksulluk olgusunun, Müslüman toplumlara has dini bir çerçeveye paralel oluştuğu söylenebilir. Nitekim dini açıdan yok- 
sulluk kadere iman ve tevekkül eksenlerinde kabul ve tahammül edilebilir bir gerçeklik olarak görülmektedir. Subaşı'na göre, “Günümüzde dinsellik ve yoksulluk arasında kurulan ilişkinin özellikle İslam söz konusu olduğunda iyice popülerleşen boyutları dikkate değer bir bilgi eksikliği içinde tartışılmaktadır. Bu bağlamda kamuoyuna mal olan iki tür yaklaşım dikkat çekicidir. Bunlardan birinde yoksulluğu besleyen ana damarın dinsellik olduğundan hareket edilmekte ve bu iddiayı desteklemek için de tarihsel bağlam israrla göz ardı edilerek, ayet ve hadisler, işlevsel sayılacak kimi örneklerden hareketle yorumlanmaktadır. Bu eğilime göre, yoksulluğu yüceltmek ve onu bir "fazilet" şeklinde göstermek günümüze dek süregelen İslâmî bir gelenek olmuştur. Diğer bir yaklaşım ise İslâm'1 yoksulluk karşıtı bir söylemin ana mihveri olarak değerlendirmekte, bu yaklaşımdan hareketle de dine aktivist bir görev yüklenmektedir. Çağdaş İslâmî siyasi düşüncede, dine çok boyutlu bir fenomen olarak yaklaşılmakta, toplumsal sorunların tamamı hakkında İslâm'ın bütüncül cevapları ve önerileri olduğu tezinden hareket edilmektedir. Din temelli bu düşüncenin hareket noktası, yoksulluğu giderecek temel argümanları İslâm'da aramak ve bulmaktır" (Subaşı, 2007, 92).

\section{Sonuç}

Nasrettin Hoca fikralarında mizah yoluyla, çok çeşitli konularda toplumsal ve bireysel eleştiri yapılmaktadır. Hoca'nın şahsında, Türk halkı olarak asırların süzgecinden geçirerek adeta kitlesel kabullere dönüştürdüğümüz değer yargılarımız kadar, yoksulluk, adaletsizlik, yönetim sistemine yönelik olumsuz tespitler gibi temel eleştiri konularımız da söz konusu fikra metinlerinde çarpıcı bir zekâ ürünü olarak ortaya konmaktadır. Evrensel boyutları da olan bu sorunlara, ilgili fikra metinlerindeki yaklaşım, halkın ortak muhayyilesinde teşekkül eden düşünce yapısını da göstermesi bakımından önemlidir. Aynı zamanda fikra türünün sorgulayıcı ve düşünmeye sevk eden mizahi yapısı, kitlesel inanış ve kabullerin sorgulanabileceği seçeneğini de sunmaktadır. Bu düşünceden hareketle, söz konusu çalışmada Hoca fikralarına yansıyan ve toplumsal bir fenomen kabul edilen yoksulluk sorunu üzerinde durulmuştur. İncelenen fikralara göre, yoksulluk olgusunun temelde kamusal bir sorun olarak ele alındığı görülmektedir. Bu bağlamda Hoca'ya atfedilen fikra belleğinde eleştirel bir yaklaşım ve mizahı buluşturan dramatik söylem göze çarpmaktadır. Toplumsal hafızanın eleştirme ve sorgulama gücünün buluştuğu bu fikralarda, birey/toplum, yönetici/yönetilen ve yaratıcı/yaratılmış eksenlerinde mizahın bir bağlam olarak hem uzlaştırıı hem de empati sağlayıcı rolü tespit edilmiştir.

İncelenen fikra metinlerine dayanarak, fikra türünün içerdiği mizahın, yoksulluk gibi son derece ciddi bir toplumsal sorunu ele alış biçimiyle soruna dair farkındalık ve yüzleşme sağladığı söylenebilir. Bu şekilde toplumsal ya da bireysel huzursuzluklara ya da gerilme dolayısıyla oluşan baskıya karşı verilmiş cevapların, söz konusu mizahi öğeyi taşıması sayesinde kitlesel rahatlamalardan ya da kabul edilebilirliklerden bahsedebilmektedir. Şüphesiz burada fikra türünün, eleştirinin odağına yerleştirdiği en acımasız ve en müstehcen konularda bile dolaylı yumuşatıcı ve sıradanlaştırıcı özelliğinin etkisi 
de bulunmaktadır. Aynı zamanda ilgili fıkra metinleri sayesinde, yoksulluğun sunuş biçimlerinin ortak toplumsal düşünüşü dile getirdiği de gözlemlenmektedir.

Notlar:

1 Bu çalışma “Uluslararası Nasreddin Hoca Sempozyumu'nda (30 Eylül-2 Ekim 2016, Eskişehir) tarafımızdan sunulan "Nasrettin Hoca Fıkralarına Yansıyan Yoksulluk Eleştirisi”" başlıklı bildirinin genişletilerek makaleye dönüştürülmüş biçimidir.

2 "Yaygın olarak kullanılan mutlak ve göreli yoksulluk kavramları yoksulluğu tam olarak karşılayamadığı ve insan kapasitesine vurgu yapmadığı için, bu iki kavramdan daha kapsamlı olan insanî yoksulluk kavramı geliştirilmiş ve yaygın olarak kullanılmaya başlamıştır”. Ayrıntılı bilgi için Bk. (Topgül, 2013,281).

3 İlgili fikra metni için Bk. (Başgöz, 1999, 36).

\section{Kaynaklar}

Açıkgöz, R., Yusufoğlu, Ö.Ş. (2012). Türkiye'de yoksulluk olgusu ve toplumsal yansımaları. İnsan ve Toplum Bilimleri Dergisi, C.1, S.1.

Ak, M. (2016). Toplumsal bir olgu olarak yoksulluk. Akademik Bakış Dergisi, S.54, Mart-Nisan, İktisat ve Girişimcilik Üniversitesi, Türk Dünyası Kırgız-Türk Sosyal Bilimler Enstitüsü, Celalabat- Kirgizistan.

Aksan, G. (2012). Yoksulluk ve Yoksulluk kültürünün toplumsal görünümleri. Konya: Selçuk Üniversitesi Sosyal Bilimler Enstitüsü Dergisi, S.27,

Başgöz, İ. (1999). Geçmişten Günümüze Nasrettin Hoca. İstanbul: Pan.

Bilgin, V. (2005). Nasreddin Hoca fikralarında toplumsal hiciv ya da halk bilgeliğinin toplum eleştirisi. I. Uluslararası Akşehir Nasrettin Hoca Sempozyumu, Akşehir: Akşehir Belediyesi Kültür Yayınları.

Boynukara, H. (2003). Edebiyatın tükenmez malzemesi: Yoksulluk. Yoksulluk Sempozyumu Bildirileri, C.3. İstanbul.

Çiğdem, A. (2016). Yoksulluk ve dinsellik, Yoksulluk hâlleri -Türkiye'de kent yoksulluğunun toplumsal görünümleri. (Ed. Necmi Erdoğan), 3. Bask1, İstanbul: İletişim. s. 203-247.

Giddens A., Sutton W. P. (2018). Sosyolojide temel kavramlar. (A. Esgin, çev.), Ankara: Phoenix. Kabacalı, A. (1991). Bütün yönleriyle Nasrettin Hoca. İstanbul: ÖzgürYayın Dağıtım.

Kurgan, Ş. (1986). Nasrettin Hoca. Ankara: Kültür ve Turizm Bakanlığı.

Marshall, G. (1999). Sosyoloji sözlüğü. (O. Akınhay, D. Kömürcü. Çev.). Ankara: Bilim ve Sanat.

Oktik, N. (2008). Yoksulluk olgusuna kavramsal ve kuramsal yaklaşımlar. Türkiye'de Yoksulluk Çalışmaları. (Ed. Ayça Duru Salıcı), İzmir: Yakın.

Okumuş, E. (2009). Bir sosyal eşitsizlik örneği olarak yoksulluğun dini meşrulaştırımı. Uluslararası Yoksulluk Sempozyumu, Yayına haz. Prof. Dr. K Tuna vd., III.Cilt, İstanbul.

Özdemir, N. (2010). Mizah, eleştirel düşünce ve bilgelik: Nasreddin Hoca, Milli Folklor, Y.22, S.87, Ankara.

Parin, S. (2009). Dilencilik bir yoksulluk kategorisi midir? Uluslararası Yoksulluk Sempozyumu, Yayına haz. Prof. Dr. K. Tuna vd., III. Cilt, İstanbul. 
Sakaoğlu, S. (2006). Nasrettin Hoca Fıkralarından Seçmeler. Ankara: Akçağ.

Sakaoğlu, S., Alptekin, A. B. (2009). Nasrettin Hoca. Ankara: Atatürk Kültür Merkezi.

Subaşı, N. (2007). Sinırları yoklamak din sosyolojisi okumaları. Ankara: Ötüken.

Şişman, B. (2010). Nasreddin Hoca fikralarındaki şahısların sosyal statülerine göre sınıflandırılması ve değerlendirilmesi. Ondokuz Mayıs Üniversitesi İlahiyat Fakültesi Dergisi, S. 28, Samsun.

Topgül, S. (2013). Türkiye'de yoksulluk ve yoksulluğun kadınlaşması. C.Ü. İktisadi ve İdari Bilimler Dergisi, C.14, S. 1, Sivas.

Yıldırım, Dursun, (1999). Türk Edebiyatında Bektaşi fikraları. Ankara: Akçağ.

Elektronik kaynaklar:

http://www.canaktan.org/ekonomi/yoksulluk/birinci-bol/aktan-vural-yoksulluk.pdf (erişim tarihi 20.11.2018)

e-Şarkiyat İlmi Araştırmalar Dergisi -www.e-sarkiyat.com- ISSN: 1308-9633 Sayı: V, Nisan 2011 